\title{
An Analysis of the Unstable Factors of the College Counselors in the New Era
}

\author{
Weiwei Wu \\ Shaanxi Institute of International Trade \& Commerce \\ Xi'an, China \\ zfwuweiwei@163.com
}

\begin{abstract}
The major contradictions of socialism in the new era have changed and put forward some new requirements on education, so the counselors' work faced significant challenges. Counselors in colleges and universities play an irreplaceable role in strengthening ideological and political education of undergraduate students and maintaining the stability of the colleges. However, at present, there are many unstable factors which influence the college counselors' construction, such as institutional level, career identity, and educational object and so on. Therefore, some prominent and urgent problems should be solved in those aspects. In view of these problems, this thesis proposes some solutions from the level of system and counselors.
\end{abstract}

Keywords-New Era; Counselors; Unstable Factors; professional identity

The 19th National Congress said: "Socialism with Chinese characteristics enters a new era, the principal contradiction in our country is that the unbalanced and inadequate development and the people's ever-growing needs for a better life.” The 19th National Congress also said: "Give priority to the development of education [1]." As an important part of educational business, colleges and universities are charged with an important mission of cultivating college students. Moreover, Counselors have great responsibility because they have to be responsible for students management and ideological and political work. In college, counselors are the organizers, implementers and mentors in the students daily ideological and political education and management. In order to ensure smooth ideological and political work of college students, a high level and strongly stable counselors' team is a must. This plays a significant role in deepening reform of education system and cultivating qualified socialist builders and successors for the great cause of socialist modernization. In the New Era, the development of a better educational business requires excellent counselors to make a little contribution, but there are still many unstable factors in college counselors' team.

\section{AN ANALYSIS OF THE INSTITUTIONAL FACTORS OF INSTABILITY OF COLLEGE COUNSELORS IN THE NEW ERA}

A. The evaluation system of the counselors' work is unreasonable

Scientific and reasonable evaluation system has important

Fund projects: The phased achievements of shaanxi social science foundation project (project no. 2015A022) in 2015. incentive and guarantee function to stabilize the counselors' team. At present, some colleges and universities have an unreasonable assessment to counselors' work. According to the "Regulations for the Construction of Counselors in Colleges and Universities", college counselors are mainly responsible for the daily ideological and political education and management of students, and their work core is "the ideological and political education of students." [2] But "some of the colleges are famous for encouraging students to participate in self-examination or other types of qualifications and they often assess the counselors' main work according to the students' examination pass rate[3]. Some of the counselors' enrollment performances are measured in accordance with the admission results, and some colleges assess the work of counselors according to the students performance, whether they have drunken behavior, fighting and so on. Moreover, some colleges give one-vote veto or dismiss the counselors due to students' personal safety accidents. Obviously, it is not rare that the unreasonable assessment of the counselor's work in colleges and universities Therefore, the counselor is faced with great risk and enormous psychological pressure during the work, and this will bring some negative impact on the stability of counselors' team.

\section{B. Lack of understanding and attention to the status and role of counselors}

"Regulations for the Construction of Counselors in Colleges and Universities" issued by the Ministry of Education states that counselors are an important part of the teachers' team and management team in colleges and universities who serve both the teacher and the cadre. Counselors are the backbone of carrying out college students' ideological and political education, and they are the organizers, practitioners and mentors to college students in their daily ideological and political education and management[4]. It can be seen that counselors play an extremely important role in students' ideological and political education and management.

However, many public colleges, including some private colleges are lack of understanding or even misunderstanding about the counselors and their roles. For many people who include some of the leaders and staff in public and private colleges, they all have a misunderstanding that people who work as counselors are those who are not competent for the post of teacher and administration, and they also believe that as long as there is enthusiasm, everyone can do counselors' work. 
Therefore, in many colleges, "the importance of the counselors' slogan shouts loudly, but very few schools really put it into practice." [5] In the actual work, counselors are only running errands, communicating information and doing the management work. As a result, even some managers in the college often shout at the counselors. In addition, there are many colleges leaders unilaterally think that the central task of college is teaching. As a counselor, they only need to manage and organize the students' learning and life affairs well, and make sure that students do not make trouble. Therefore, in their daily work, counselors are often in a forgotten position. So how can professionalization and specialization of counselors' team be implemented and strengthened? Under such circumstances, how can counselors see their bright future? Not only that, they have to endure spirit and job discrimination, so they decide to leave.

\section{The orientation of counselors is not clear}

"Regulations for the Construction of Counselors in Colleges and Universities" have clearly defined the main responsibilities of college counselors, namely, counselors should educate the students on ideology and politics and cultivate their moral character, dissolve the contradiction of the students to maintain campus security and stability, implement the aids of economically difficult student, carry out student employment guidance and service, guide student party branch and class committee, and cultivate student backbone.

But in many colleges and universities, counselors not only have to shoulder the above responsibilities, but also often do work beyond their duties. This is mainly reflected in two aspects: Firstly, counselors need to be fully responsible for all of the work related to students, almost everything. For example, counselors are not only responsible for the students' study, life and psychological, but also responsible for student attendance, dormitory management, military training and other business, and even they need to help students to solve love affairs, affections and other related thing. Secondly, in some colleges and universities, counselors also need to deal with faculty relocation, teaching arrangements and daily activities and so on for various reasons. In addition, some colleges do not have perfect internal management system and mismanagement. In fact, some departments which should be responsible for the management of students' life and activities do not fulfill their responsibilities fully, and then the counselors have to subrogate management functions. It also can be seen that in many colleges and universities, the role of counselors are inaccurate and the responsibilities are unclear, so counselors often work in unbearable overload.

\section{Counselors have low salary and poor working conditions}

Counselors have low salary. On the one hand, the ideological and political education about students are complex, student management workload is large and trivial, as well as heavy work not under their duties, it can be said that the counselor's workload is as much as that of full-time teachers. However, in many colleges and universities, counselors' wages and material rewards are much lower than those of full-time teachers, and even in some colleges and universities, such things as arrears wages, abuse probationary and no payment of insurance may occur. About the accommodation, in some colleges and universities, due to the college condition limits, counselors have to crowd in dormitory or student apartments. On the other hand, owing to the particularity of the counselor's work, it is common that counselors have to work overtime at night and weekend. Not only did they give up their spare time, but they often had no overtime pay. In addition, when a student is ill or has something like that, the counselor will inevitably have to pay some hidden costs such as fares, but they will receive few or no telephone fees, transportation subsidies.

Not only the material treatment of counselors is low, but also office conditions are also poor in some colleges and universities. For example, some schools, due to the limited conditions, many counselors can only squeeze in one office and the office has nothing except the necessary office supplies. It's a humble office environment.

\section{E. Strict demands on Counselors}

Now many colleges and universities are located in the remote suburbs, which greatly limit the counselor's social activities. Not only that, the counselors' work is still rather long, and many colleges and universities ask them to live with students in the dormitory and do not leave the school during the weekday, and that is more limited to their social aspects, especially bad for young single counselors. The personal problems of counselors can inevitably affect their work mood and job stability.

\section{AN ANALYSIS OF THE OCCUPATIONAL FACTORS OF INSTABILITY OF COLLEGE COUNSELORS IN THE NEW ERA}

\section{A. Counselors have low recognition of their professional identity}

In recent years, many young college students and a number of graduate students have joined the college counselors' team. This helps to improve the overall quality of counselors in a certain sense. But it also affects the instability of the counselors, because some of the counselors are forced to make the choice by the current employment situation instead of their interests and acceptance to this occupation. It is clear that many of them hold on to the current job while seeking a better one. Counselors also choose to job-hopping if they have any opportunity or condition, so these inevitable results in a loss of counselors.

\section{B. Young counselors are inexperienced and stressed}

College counselors are doing work related to students, and its work object is the students who come from all corners of the country with different educational background, active thinking, and individual character, so the difficulty of the work can be imagined. Therefore, Counselors should not only have a solid foundation of ideological and political theory, but also have the related knowledge of pedagogy, management, psychology, organizational behavior, sociology and so on. Moreover, at present, a large number of counselors are college graduates, relatively speaking, they lack of social practice, social experience and work experience and training. But many colleges and universities do not pay enough attention to the 
training of counselors, which makes it is hard for them to achieve satisfactory results, although they put in a lot of time. So they may find it difficult to work and choose to change profession or quit.

\section{AN ANALYSIS OF THE EDUCATIONAL OBJECT FACTORS OF THE COLLEGE COUNSELORS IN THE NEW ERA}

Due to the multi-level and diversified forms of higher education in China, most of the students come from senior high school and some from junior high school or secondary school. It can be seen that college students are a group with different educational background, uneven cultural foundation, active thinking and outstanding personality. Thus, they show the following characteristics in study and life: First, although most of them have higher moral qualities and their own ideal pursuits, many students are susceptible to the interference and influence of the external environment in various reasons, and their moral behavior is prone to deviation. Second, although they have a good sense of time and discipline, agree with the rules and regulations of the school and can consciously abide by, but due to lack of long-term self-restraint and selfmanagement ability, bad habits, "personality" thinking and pursuit of fashion, they begin to relax themselves, and some bad habits and problems are exposed after a period of time in college. In addition, they may also skip, drink, fight and violate against school rules or disciplines. All of these add to the difficulty of managing to counselors, and coupled with the above-mentioned conditions about the private colleges, some counselors force to give up due to unbearable pressure.

\section{Some Suggestions on StABILIZING COLlEgE COUNSELORS IN THE NEW ERA}

\section{A. Improve the relevant system and guarantee the stability of the counselors team}

First of all, colleges should correctly understand the importance of counselors and pay attention to the construction of them. Counselors are an important guarantee for the operation of the school system and the effective development of teaching work, so colleges should have a correct understanding of their importance and encourage them on the policy, such as letting the counselors go out to study and enhance their management skills, encourage counselors to pursue further studies. Meanwhile, various activities can be held in colleges to promote cooperation and exchange among counselors. In selecting administrative personnel, the colleges may give priority to the counselors' team.

Second, colleges should establish a scientific and reasonable counselor management system, especially the evaluation system. Based on the performance of counselors, colleges should develop a systematic, scientific and reasonable system and abolish some non-scientific indicators, such as the enrollment system. Because counselors are main responsible for managing students, enrollment is the responsibility of enrollment office. Therefore, it seems far-fetched to use this indicator to measure a counselor's job. For alcohol abuse, it is not scientific and unreasonable to directly deny the process which shall be in accordance with the different circumstance. Based on humanitarianism and law, colleges can develop a scientific and comprehensive counselor's working rule on the basis of their own situation so that the counselors can be clear about their rights and obligations and do things in accordance with laws. Moreover, Counselors exercise their rights and obligations in accordance with the rules and regulations, and avoid unclear orientation and unclear responsibilities of counselors. Of course, the regulations should not be too stringent, for example, counselors and students must live and eat together, counselors must live in college, and some other inhuman behaviors which deprive some rights of counselor. Counselors also have their own families, but some schools let the counselors live in department for 24 hours a day and only take one day off each week, which makes counselors have no time to take care of their own family life.

Finally, colleges should improve counselors' working conditions, raise incomes, set special allowances, and implement them effectively. Counselors' work is special, and they have to be responsible for everything about students. Therefore, they bear a heavy workload and long working hours. However, counselors have a meager salary. To retain good counselors, salary is a very attractive factor. The majority of counselors are young, married and having children, so their families burdened are heavy. If they do not have a good remuneration, it will inevitably affect the stability of the counselors' team and many of them may want to change jobs. In practice, all of these make them lack of motivation and negative attitude towards work. While some schools do not set special subsidies for counselors, such as telephone subsidies, transportation subsidies, etc., which will also affect the counselors' work.

\section{B. College counselors in the new era should cultivate their own professional identity}

Due to family background, personal experience and different ideals and beliefs, counselors have different personal opinions for this profession. Some people like it and regard it as a life-long career, but some others dislike this job, and even think it is boring, they have to do the job due to various reasons. Surely, there are many talented people in the counselor team. For the counselors, first of all, it is necessary to establish a serious attitude, do everything seriously, and do it well, including things related to students. Counselors should find fun in the work, invest time in work, and only in this way, they will be rewarded and have a full sense of gain. Rather than swaying, it is better to do it seriously. Secondly, although counselors' work is trivial, it is a great undertaking. When they face many different kinds of students, they also face many challenges, so they should handle it properly. Counselors also should have a correct view about their work. When the students encounter difficulties, counselors should help them to solve, because this is a very happy thing to students and to counselors. Today, many leaders are selected from the team of counselors; we can see that the counselors team is a place for improving ones' ability. Finally, counselors should improve themselves and their ability. If counselors just work because this is a job, it is easier to do, but if they want to do it as a career, it is rather difficult. To do the work better, counselors need psychology, education, political science, management, and other knowledge, therefore, counselors should keep 
learning, improve themselves, and then they can handle the work easily, make the students convince, get a sense of accomplishment and professional identity. Therefore, we must strengthen our ideals and beliefs and cultivate professional identity.

\section{CONCLUSION}

"The way to seek for the truth is long and difficult, but I will try my best to go for it", the responsibility of counselors is great and they should work harder. Counselors should love whatever they do and combine their ideals and beliefs with their identities and responsibilities to realize their "Chinese dreams" in ordinary posts. Although there are still many factors that affect the team of counselors, these unstable factors will be gradually resolved under the joint efforts of relevant departments, such as colleges. With the joint efforts of the college, society and counselors, counselors' team will become more and more powerful and outstanding.

\section{REFERENCES}

[1] Xi Jinping. Speech at the Nineteenth Congress of the Communist Party of China. People's Daily, 2017,10 (18).

[2] Huang Zhijian. The main reasons and countermeasures of the instability of college counselors. Education Exploration. 2007, pp.71-72.

[3] Zhou Kun, Shen Pingxia. Investigation and thinking on the present situation of counselors in private colleges and universities in Shaanxi province. New West. 2009, pp. 114,119.

[4] People's Republic of China Ministry of Education website. Ministry of Education of the People 's Republic of China No. 24.

[5] Jia Jing. An Analysis of the Realistic Factors Affecting the Steady Work of College Counselors and the Countermeasures. Journal of Hubei Radio \& TV University. 2009, 29 pp. 47-48. 